\title{
Socio-Economic Empowerment of Women through Self Help Group Bank Linkage Program helping in minimizing Regional Disparity in Hyderabad
}

\author{
Rehana Sultana \\ PhD Scholar, Dept. Of Economics, MANUU
}

\begin{abstract}
As women occupy half of the world population, they are the basic unit of a family and perform multidimensional tasks. The first Prime Minister of India Jawaharlal Nehru says, "You can tell the condition of a nation by looking at the status of its women". This study emphasizes the Socio-economic Empowerment of women through a Self Help Group Bank Linkage Program helping in minimizing regional disparity in Hyderabad. . Few areas are too developed and few are backward. In India 70 per cent of the population lives in rural areas where 75 per cent people associated with agricultural sector. So every area women recident must be empowered is the main objective of this programme. With the help of percentile analysis, the authors explain how various variables are related to women Empowerment, i.e., children education, health, increment in women abilities. For the organized analysis of the study, Krejcie and Morgan table used to determine the sample size. 100 SHG-BLP members, interviewed through an unstructured interview schedule. The need to is bring change in the financial resources and incremental business training for women to empower them, to have a decent and joyful lifestyle, and to tackle multidimensional problems. However, the extreme need for the program is better improvement so that women can fully utilize this program and climb up their business abilities in all regions.
\end{abstract}

Keywords- Socio-Economic Empowerment of women, Self Help Group Bank Linkage Program, Multidimensional Tasks, Self Sufficiency.

\section{INTRODUCTION}

Socio-Economic Empowerment of women means the quality of adjusting oneself in a new and unknown situations. Empowerment creates confidence in dealing with day-to-day situations and stress to come out of particular circumstances. Empowerment of women means the ability to tackle new conditions and multidimensional problems. The status and importance of woman in the society displays how much they are empowered.

Socio-Economic Empowerment of women means the freedom to think, act, and choose, which completes the equal status of the individual in society. Socio-Economic Empowerment of women means the right to control the matters of life and make necessary changes. It is a process that produces changes in thoughts awareness of rights and opportunities of the individual in all walks of life product development.

\section{Self Help Group Bank Linkage Program in minimising regional disparity}

In 1956, Dutch social welfare, J. E. Dejongh presented a paper in an international seminar; promoting cooperative action and social improvement through the Self-Help Group Bank Linkage Program.

To ease poverty, the World Bank provides free small loans, in parts, to Mohammad Younus' concept of partial liability for income-generating activities. In 1938, Several Asian countries took various steps for the inclusion of poor people. For the development of the poor in many continents, like the Pacific Ocean, Latin America and Africa adopted inclusive measures on the pattern of Mohammad Younus of Bangladesh. So Mohammad Younus of Bangladesh undertook extraordinary activity through the Partial Finance Self Help Group in 1976. The World Bank conducted Mohammad Younus' conceptual partial debt. To ease poverty, the World Bank provides free small loans, in part, to Mohammad Younus' concept of partial liability for income-generating activities.

\section{Socio-Economic Empowerment of Women through SHGs in minimising regional disparity}

Since the first five-year plan, many programs were implemented through the Self Help Group Linkage Program, launched by NABARD in 1992. This program originated from the SHGs 500. Which is a group of 10-20 people? If disabled, a group of 5 people formed so that these groups have several sessions to be aware of all matters. Group members should be on the same street in the same area. In this sense only same area people can make a group to develop each other. So this particular programme objective is to cover and develop all area women residents in gross root level. It will minimise 


\title{
International Advanced Research Journal in Science, Engineering and Technology
}

\author{
Vol. 8, Issue 8, August 2021
}

\section{DOI: $10.17148 /$ IARJSET.2021.8853}

regional disparity if all women is empowered and help each other in there development It resolves conflicts with the help of collective leadership and mutual discussion They can get a loan from group funds and pay for group members' shortterm needs.

\section{REVIEW OF LITERATURE}

The relevant literature analysis guides the researcher to further research and offers a direction to research. In addition, the review of literature tells the researched the problems and their solution during the research. In the following study of literature, the researcher studied research papers, books, articles and thesis, related to the Self Help Group Bank Linkage Program, which they described all are chronological, and it covers both international and national level studies.

The swot on women empowerment in Sri Lanka revealed that women's role in a household, decision-making and control over money matters the independent flexibility between women and husbands' education, participation, waged work, and family structure. The research findings were that work for pay and training increased only decision-making input in financial but not in the social and organizational matters in the household (Malhotra and Malhotra 1997).

Frankenberg and Thomas attempted to understand women's Empowerment in Indonesia. Socio-Economic growth measures were role and control in household decision-making, use of time, cash spend, autonomous flexibilities taken as the relative status of spouse at marriage like education, age, and social status as the family origin. In addition, this study observed that status influenced financial arrangements and decision-making power (Frankenberg and Thomas 2001).

In this study, Hund and Kasynathan analyse microfinance and transformation in gender relations in South Asia. Differing point of view that finance would revise in the light of evidence that the most impoverished families and the access to credit are so far for the poorest women. Development agencies need to recognize and accept that microfinance did not directly or automatically empower women, gender transfiguration and documentation. It required a range of microfinance packages to meet the need of both the poor and the poorest. Required a sequent track to enable, and the program has a specific goal. That helps women's superb control of decision making and various options in life (Hund and Kasynathan 2001).

Rahman and Khan elaborated the microfinance provided collateral-free loans to poor women in a rural area that repayable in the rural area that was refundable infrequent and easy instalments. These types of provisions are active for poverty reduction. To improve health education, legal rights, sanitation, and other living standards in all microfinance programs, women-focused and targeted are the most vulnerable part of society as they live in a household without assets. The provision of collateral-free loans to poor people is the opportunity for self-employment somewhat improved, woman's security and self-confidence because of that the status in household developed such improved women empowerment (Rahman and Khan 2007).

While in the study, Mustafa women in Bangladesh observed three dimensions of domestic autonomy, like a performer of economic decision-making power and physical freedom of movement; the research aims to represent the women's empowerment index and social character like age, the age at marriage, and the difference between husband and husbandwife. The study found that urban women were more empowered than rural women, and older women had freer and more autonomous than younger women because of their life experiences. In addition, the study observed the rise in awareness about women's rights and fundamental needs (Mustafa et al. 2008).

\section{PROBLEM STATEMENT:}

Women's self-sufficiency through the Self-Help Group Bank Linkage Program is essential is eliminate poverty in the present. Self-help groups work on the principle that self-help is the best self-help, the same principle, self-help groups work and support group members on time. For the poor, it is a support infrastructure that allows them to become successful individuals.

\section{The Problem of the Study:}

The poorest people exploited in the capitalist system, which is why our mujahedeen were against independence, and our first prime minister was against it and convinced of socialism, but the financial and social conditions of the present are suitable for the democratic system. Were as the combined system for rapid national development had adopted by the Government (Mixed Economy). However, the rich and the rich are getting poorer and poorer. $80 \%$ of the country's resources owned by $20 \%$, and only $20 \%$ of the funds shared by $80 \%$. In a densely populated massive country like India, people have a hard time accessing resources. Such situations create compulsion and resentment in public. An unsatisfactory one creates an environment. To overcome such a case, to eliminate imbalances and to develop women, the government promotes a range of programs in every five-year plan, which encourages the poorest of the few.

Since the first five-year plan, many programs had implemented the self-help group Linkage Program, launched by NABARD in 1992. This program originated from the SHGs 500. Which is a group of 10-20 people? If disabled, a group of 5 people formed to have several meetings to be aware of all matters. Group members should be on the same street in the same area. They can get a loan from group funds and pay for the short-term needs of group members. It avoids paying 


\title{
International Advanced Research Journal in Science, Engineering and Technology
}

\author{
Vol. 8, Issue 8, August 2021
}

DOI: 10.17148/IARJSET.2021.8853

substantial interest to local business people or spread their hands to their loved ones and relatives when the time comes. In this way, SHG members will create a positive identity at home by sharing the financial burden.

\section{Objectives of the Study:}

Following are the objectives of the study:

1. To know the effects of socio-economic growth of women through SHG-BLP.

2. To study the positive impact of education and health of women through SHG- BLP.

\section{HYPOTHESIS OF THE STUDY:}

1. To empower women through SHG-BLP socially and economically.

2. SHG-BLP is attracting women towards savings.

\section{Tools of the Study:}

Primary and secondary both methods used to complete this paper. Information got through the questionnaire, interviews, and all information entered through the observation. The Case Study Method used to study the problem in depth.

Secondary research used various books, journals, research papers, the Internet and reports published by NABARD and more.

\section{Study Patterns:}

The researcher has used a probability sample of research. The Purposive Sampling Method for this research. Percentage Analysis Percentage Analysis used in Statistical Technique. All the information presented as tables and graphs.

The area of the city of Hyderabad is $625 \mathrm{~km}$ sq. $\mathrm{km}$ (two thirty-seven 241 square miles). The city has a total population of 9,507,434 (9.5 Million). They divided Hyderabad into five zones to facilitate discipline. These areas divided into circles.
1. Kapra Circle in the East Zone
2. Mughalpura Circle in South Zone
3. Adikmet Ward in Central Zone
4. $\quad$ Kukatpally Circle from West Zone
5. Ambedkar Nagar Ward from North Zone

For this study, both primary and secondary types of methods used. Information got through a questionnaire in the Primary Method of Data Collection. The questionnaire planned for the info and systematic analysis of all variables relating to women's autonomy, such as self-esteem, decision-making, health, children's education, and women's ability development. (100) questionnaire filled out by interviewing women. The researcher interviewed for the research. Some closed questions and some open questions put in the questionnaire to understand these women's views better.

Table 1: Monthly Income of the SHG Members and Chart.

\begin{tabular}{|l|l|l|}
\hline Monthly Income & Number of Member & Percentage \% \\
\hline $1000-3000$ & 28 & 28 \\
\hline $3000-5000$ & 16 & 16 \\
\hline $5000-7000$ & 03 & 03 \\
\hline $7000-10000$ & 03 & 03 \\
\hline $10000-15000$ & 01 & 01 \\
\hline $15000-$ Above & 01 & 01 \\
\hline No Income & 48 & 48 \\
\hline
\end{tabular}

Here, the increase in the income level of such SHG members here refers to the women's monthly income changes and how many women earn each month. The graph below reveals that $28 \%$ of SHG members have a monthly income of $3000-$ $1000.16 \%$ of women's monthly income is $3000-5000.3 \%$ of women's monthly income is $5000-7000$ and more $3 \%$ of women's monthly income is $7000-10000.1 \%$ of SHG member's monthly income is $10000-15000$, such as $1 \%$ of SHG member's monthly income is $10000-15000$, whereas $48 \%$ of women's Monthly income is nothing. So, most women of such SHG have no income, and at least one per cent of women have incomes of over 15 thousand. The reason is that their income level is low. 
Vol. 8, Issue 8, August 2021

DOI: 10.17148/IARJSET.2021.8853

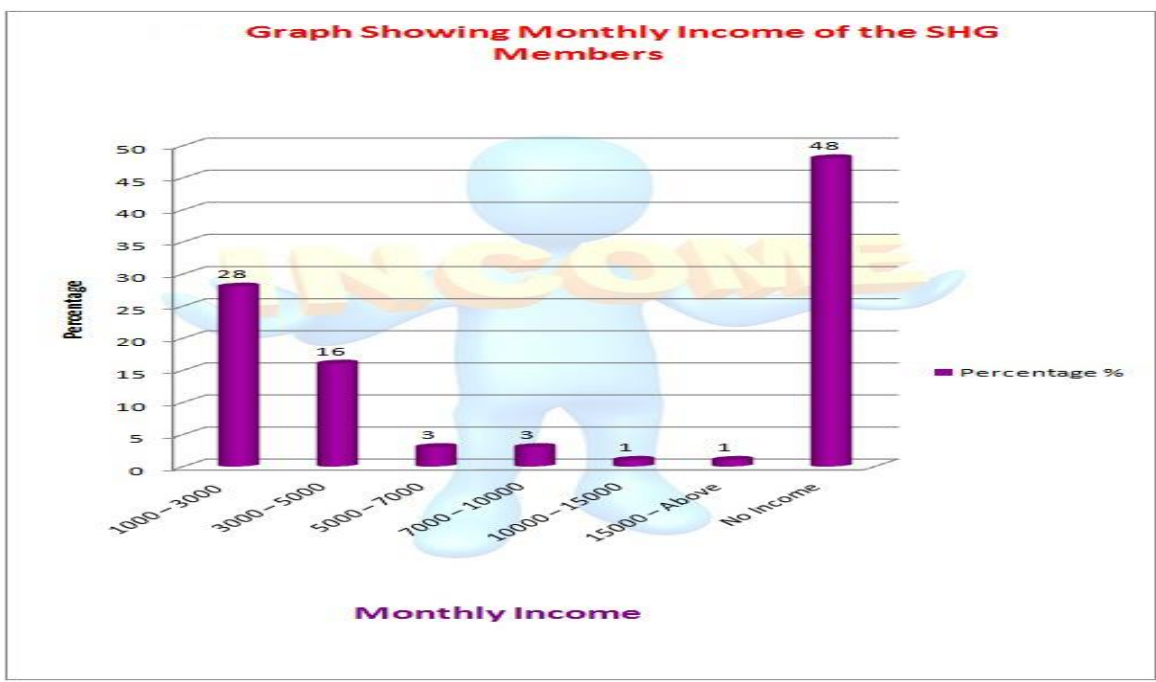

Table 2: Occupation of the SHG Members and Chart.

\begin{tabular}{|l|l|l|}
\hline Occupation & Number of Member & Percentage \% \\
\hline Professional & 30 & 30 \\
\hline Own Shop & 06 & 06 \\
\hline Skill Workers & 03 & 03 \\
\hline Semi-Skilled Workers & 01 & 01 \\
\hline Un Skilled Workers & 06 & 06 \\
\hline Others & 06 & 06 \\
\hline Un Employed & 48 & 48 \\
\hline
\end{tabular}

Here is the information about the business of the SHG member who had employed to meet their needs. The following graph shows that $30 \%$ of the SHG women are from different professions, and $6 \%$ of women own shops (Kirana, Cosmetic, Stationary, Xerox, Bakery, Dairy Produc unskilled, and 6\% women are engaged in other works. ts.). 3\% women are skilled workers like (Tailor, Beautician, Zari work and bangle making.), $1 \%$ women are Semi-Skilled Workers like (Domestic paper.), 6\% women are engaged in other works whereas $48 \%$ are unemployed.

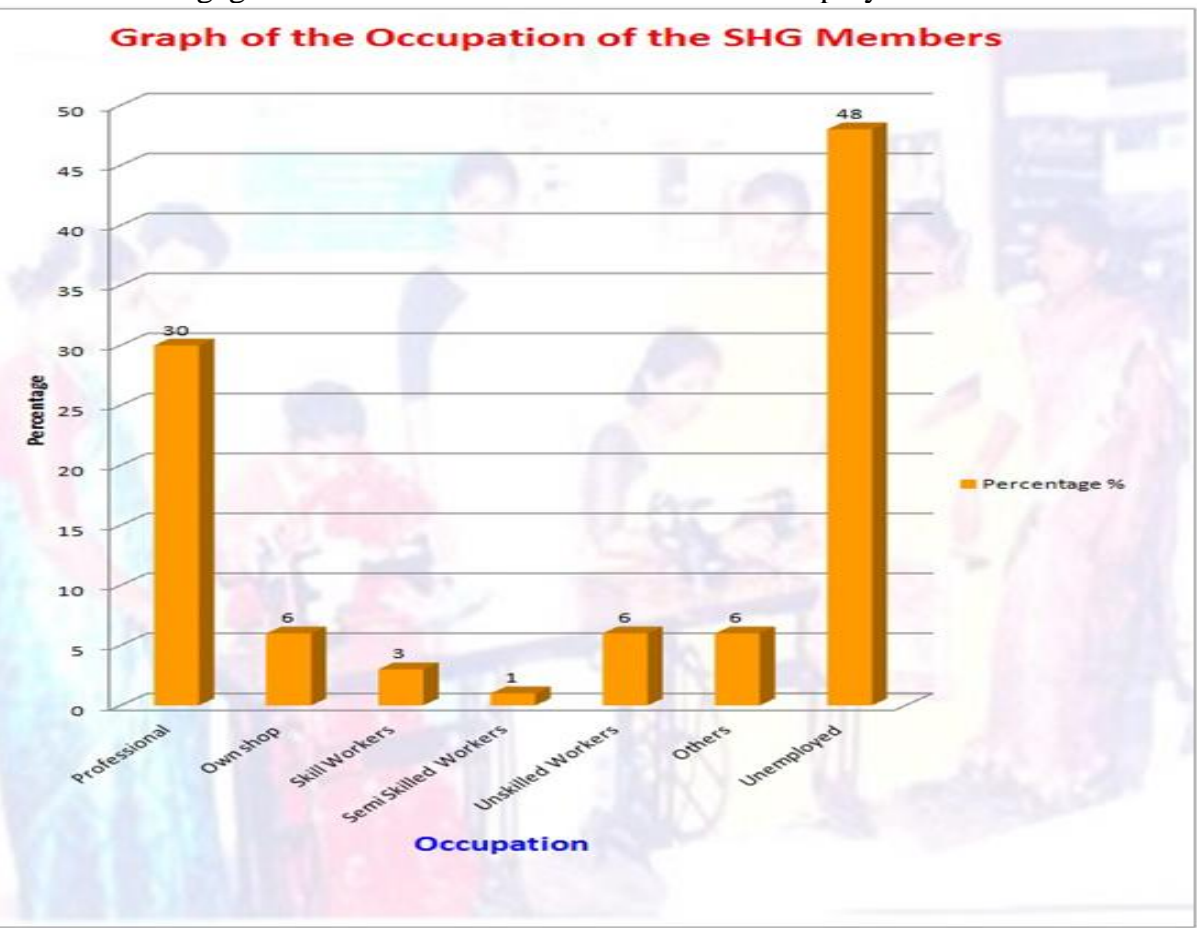


Vol. 8, Issue 8, August 2021

DOI: $10.17148 / I A R J S E T .2021 .8853$

Table 3 Improvement in Children's Education and Chart.

\begin{tabular}{|l|l|l|}
\hline Improvement in Children's & Number of Member & Percentage \% \\
\hline Yes & 56 & 56 \\
\hline No & 39 & 39 \\
\hline Both & 05 & 05 \\
\hline
\end{tabular}

To know about the changes in the Children of SHG members, i.e. whether their behavior had positive changes in the culture and education literature style. Table 3 and Graph show that $56 \%$ experienced positive changes in their children after becoming a member. $39 \%$ of women did not find any change in their children, while $5 \%$ of women found changes and did not find any change in their children. It is how we can say that most women's children have undergone some change since becoming an SHG member.

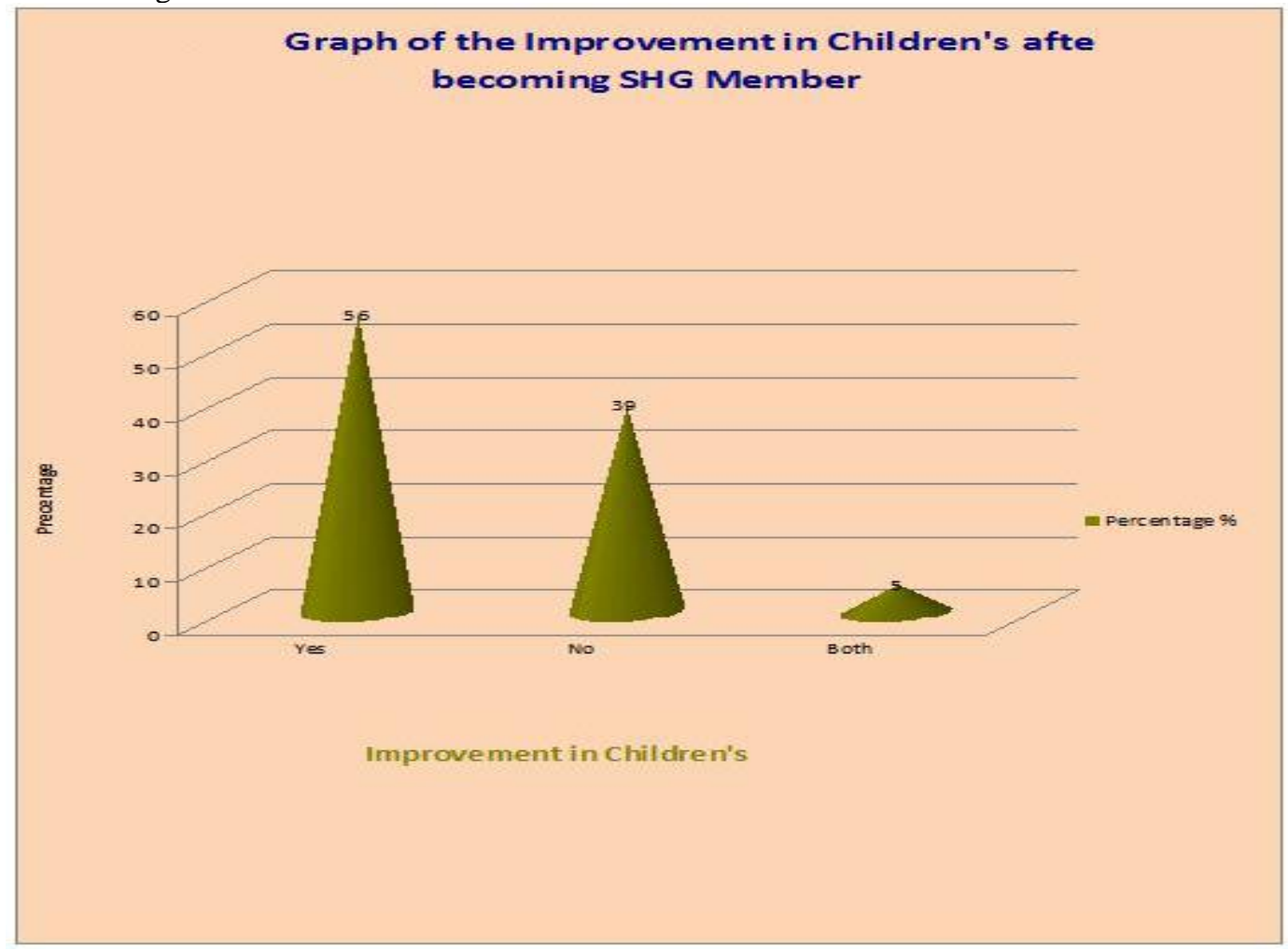

\section{Finding of the Study:}

1. $47 \%$ of the excluded women have attained secondary education. Only $10 \%$ of the women have studied till the Intermediate.

2. The income of $28 \%$ of excluded women is Rs. 1000 to Rs. 3000 , only $16 \%$ of women's income is Rs. 3000 to Rs.5000. $48 \%$ of women have no income, homeless women and have no means of income. They say that the women who cannot work outside the home should have the means to work nearby to stay home, to earn revenue.

3 . $30 \%$ of women connected to some profession, but the worrying situation is that $48 \%$ of women are unemployed. They want to do something for their development while living in their homes, but they do not need any work.

4. $28 \%$ of women trained by SHGBLP for skills development received training in computer use, maintenance of accounts, while $72 \%$ of women received no training. Despite their demand, no one got training.

5. $\quad 9.7 \%$ of women protested against being a member of the SHG's Group, while $93 \%$ of the expelled women had no barrier from their own homes.

6. The deposit in the duplicate group accounts, but their loan not approved, while $74 \%$ of women have not had a hard time getting a loan. 10. 26\% had difficulty getting cologne; $20 \%$ of the deported women belonging to the Mughalpura ward formed the group for two years.

7. All women go to the health care clinic. However, $38 \%$ of excluded women go to the government hospital, and $62 \%$ of the excluded women benefit from the private hospital.

8. $18 \%$ of women reported improvement in their health after becoming a member of SHG-BLP, while $82 \%$ of women did not feel any change in their health. 


\title{
International Advanced Research Journal in Science, Engineering and Technology
}

\author{
Vol. 8, Issue 8, August 2021
}

\section{DOI: 10.17148/IARJSET.2021.8853}

9. $43 \%$ of expelled women teach their children in public schools, $49 \%$ of women teach in private schools, while $8 \%$ of deported women teach their children in public schools in both schools.

10. $56 \%$ of women improved their children's education, money, and morals. After becoming members of SHGs, $39 \%$ of expelled women did not see any change in their children.

\section{Confirmation of Hypothesis:}

The researcher has planned all two hypotheses. Based on the main findings of this study, the researcher has thus confirmed the following hypotheses.

1. SHG-BLP is an increasing attraction towards women in savings.

* Through this study, we confirm the assumption that women whom SHG-BLP expels are attracting savings.

2. Empowering women financially through SHG-BLP

* Through this study, we confirm the notion that excluded women are not financially independent.

\section{CONCLUSION:}

Self-Help Group Bank Linkage Program is a process of inclusion from exclusion, which paves the way for women's development. It enhances women's ability to think, speak and work. Instead of different religions, cultures, levels of education through group meetings and samikhya meetings, mutual understanding and harmony created. They give SelfHelp Groups fund loans to group members on easy terms, through which excluded women can meet immediate needs. They avoid falling into the trap of traditional money-laundering entities and from more exclusion. To control multidimensional problems and bringing required changes. Training entrepreneurial and financial resource is an excellent way for women to live a dignified life. However, there is an extreme need to improve the program to utilize completely to grow up entrepreneurial capabilities.

\section{REFERENCES:}

Books

1. A. Abdul Raheem (2011), "Women empowerment through Self Help Group (SHGs)", New Delhi: New Century Publication, pp.1, $10-13,19,95$.

2. Chatterjee, Shankar (2011), "Implementation of rural development programme".

3. Danial, Lazar \& Palanichamy (2008), "Micro Finance and Poverty Eradication: Indian and Global Experience", New Century Publication, March 2008, pp.61, 142, 421.

4. Danial, Lazar \& Malabika, Deo, "Micro Finance Performance: Evaluation and Enterprises Development", pp. 4, 44, 67, 114, 245.

5. Das, S. K and Nanda, J. B. P. Rath (2008), "Micro Finance and Rural Development in India", New Delhi: New Century Publication.

6. Fisher, Thomas and Sriram, M. S. (2011), "Micro-credit: Putting development back into micro-finance", New Delhi: Vistar Publication.

7. Kapoor, G. P. (2011), "Micro-finance and women empowerment", New Delhi: A.P.H. Publishing Corporation, pp. 54, 58, 62.

8. Karmakar (2008), "Micro finance in Indi", Sage Publication.

9. Karmakar, K. G. (2009), "Rural Credit \& Self - Help Groups", New Delhi: Sage Publication.

10. Kumar Das, Kumar Jena, Kanti Das (2011), "Micro-finance: And empowerment rural poor in India", New Delhi: New Century Publication. Journals

1. Ashutosh Jindal (2005), Micro Finance and SHGs: Role of Government Institutions, Economic and Political Weekly, Vol. 40, No. 38 (September 17-23 2005), pp. 4178-4179.

2. Back Matter, Economic and Political Weekly, Vol. 38, No. 30,

(July 26-August 1, 2003)

3. Bishnu Maya Dhungana (2010), The Role of SHGs in Empowering Disabled Women: A Case Study in Kathmandu Valley, Nepal, Development in Practice, Vol. 20, No. 7, (September, 2010), pp. 855-865.

4. Cynthia Arku and Frank S. Arku (2009), More Money, New Household Cultural Dynamics: Women in Micro-Finance in Ghana, Development in Practice, Vol. 19, No. 2, (April, 2009), pp.200-213.

5. Daniel J. Leab (1966), Barter and Self Help Groups 1932-33, Midcontinent American Studies Journal, Vol. 7, No. 1, (Spring, 1966$)$, pp. 15-24.

6. From Marginal Tinkering to Major Changes: Micro Finance and Poverty Alleviation, Economic and Political Weekly, Vol. 42, No. 5, (February 3-9 2007), pp. 349-352.

7. Hans Dieter Seibel and Shyam Khadka (2002), SHG Banking: A Financial Technology for Very Poor Micro Entrepreneur, Saving and Development, Vol. 26, No. 2, 2002, pp. 133-150.

8. K. Kalpana (2005), Shifting Trajectories in Micro Finance Discourse, Economic and Political Weekly, Vol. 40, No. 51, (December 17-23, 2005), pp. 5400-5401, 5403-5409.

9. Mahendra Varman P. (2005), Impact of Self Help Group on Formal Banking Habits, Economic and Political Weekly, Vol. 40, No. 17, (April 23-29, 2005), pp. 1705-1713.

10. N. B. Shete (1999), Alternative Models of Micro Finance: Experiences of Commercial Banks/Models Alternatives De Micro Financial Experience Des Bangui's Commercials Indigenes, Saving and Development, Vol. 23, No. 4, (1999), pp. 475-487.

11. P. Satish (2005), Mainstreaming of Indian Micro Finance, Economic and Political Weekly, Vol. 40, No. 17, (April 23-29, 2006), pp. 1731-1739.

12. R. Vijaykumar (2009), Reinstating the Self Help Group Perspective in Micro Finance, Economic and Political Weekly, Vol. 44, No. 15, (April 1117, 2009), pp. 68-69.

13. S. Gulab and N. Chandrasekhar Rao (2003), Women's Self Help Groups, Poverty Alleviation and Empowerment, Economic and Political Weekly, Vol. 38, No. 12/13, (March 22- April 4, 2003), pp. 1274-1283.

14. S. M. P. Senanayake and S. P. Premaratna (2006), Micro Finance for Accelerated Development, Saving and Development, Vol. 30, No. 2, 2006, pp. $145-168$.

15. Vasant Kannabiran (2005), Marketing Self - Help, Managing Poverty, Economic and Political Weekly, Vol. 40, No. 34, (August 20-26, 2005), pp.3716-17, 3719. 